\title{
HUMANS AS PEDAGOGIC CREATURES: Islamic and Western View
}

\author{
Muh. Akib D. ${ }^{1}$, Ridwan Idris ${ }^{2}$ \\ ${ }^{1}$ Fakultas Tarbiyah IAIN Parepare \\ ${ }^{2}$ Fakultas Tarbiyah dan Keguruan UIN Alauddin Makassar \\ Email: muhakib31@gmail.com ${ }^{1}$, ridwan.idris@uin-alauddin.ac.id ${ }^{2}$
}

\begin{abstract}
:
The essence of human creation in Islamic perspective refers to the text of the Koran in terms of khalaqa (creating) and ja'ala (making). Both elements can grow through the educational process. This perspective points that humans are naturally pedagogical beings with the potential for education. This paper aims at elaborating the essence of humans as pedagogic creatures, both in Islamic and Western views. This study relied on library research for its findings. The information was gathered from a variety of books and papers on the subject. In the Islamic view, the level of education development, along with the pedagogical process that initiates it, involves informal, formal, and non-formal education. However, in the Western view, there are two categories, namely navitism and behaviorism.
\end{abstract}

\begin{abstract}
Abstrak:
Hakekat penciptaan manusia dalam perspektif Islam dengan merujuk pada nash Alquran pada istilah khalaqa (menciptakan) dan ja'ala (menjadikan). Kedua unsur itu dapat berkembang melalui proses pendidikan. Perspektif ini menyatakan bahwa manusia secara fithrawi disebut sebagai makhluk paedagogiek dengan potensi untuk dapat dididik dan dapat mendidik. Artikel ini bertujuan untuk memaparkan hakekat penciptaan manusia sebagai makhluk paedagogiek, baik dalam pandangan Islam maupun Barat. Penelitian ini menggunakan penelitian kepustakaan. Data pada penelitian ini diambil dari berbagai buku dan artikel yang berkaitan dengan topik tersebut. Dalam pandangan Islam, tingkat perkembangan pendidikan manusia, seiring dengan proses paedagogis yang mengintarinya meliputi pendidikan informal, formal, dan non formal. Sedangkan dalam pandangan Barat, ditemukan dua kategori yaitu paham navitisme dan paham behaviorisme.
\end{abstract}

Keywords:

Creatures, Fithrah, Humans, Pedagogis

How to Cite: Akib, M. D. \& Idris, R. (2021). Humans as Pedagogic Creatures: Islamic and Western View. Lentera Pendidikan : Jurnal Ilmu Tarbiyah dan Keguruan, 24(2), 316-327. https://doi.org/10.24252/lp.2021v24n2i13.

\section{INTRODUCTION}

In the Islamic perspective, humans are 'abdullah and khalifatullah. As 'abdullāh, humans must devote themselves to Allah SWT as in Surah Az-Zariyat/51: 56.

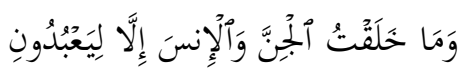

"I did not create human and jinn but for them to worship me"

As khalīfatullāh, humans must manage this world well, Allah says in Surah alBaqarah/2: 30 . 


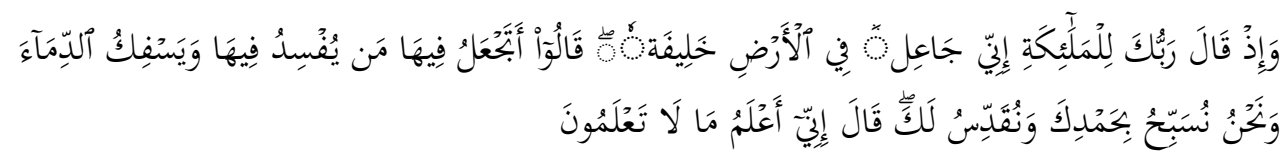

"And remember when the God-Muber said to the angels, "I will make the caliph on earth." They said, "Are you going to make someone who corrupts and sheds blood there, while we praise You and purify Your name?" He said, "Truly, I know what you do not know."

Talking about a man by highlighting his various aspects is like entering a very deep valley. It is said that because the talk about humans has been a central theme from time to time, and (maybe) has never been answered in a final way. There have been many experts or world figures (Islam and the West) who have revealed the nature of humans. Their discussion of human nature focuses on the discussion of human psychology and personality.

Dalyono (2015) revealed that scholars in both Islamic and Western education agree that humans are composed of a combination of body and soul. The body is formed according to biological principles, while the soul is formed according to physiological principles. Humans are equipped with limbs and parts of the body for the continuation of the life of the soul. The body performs soul-driven actions in certain ways. The work of the soul in the body is in the form of using mental functions that are not mental, while the work of the soul in the nervous system and the mind is in the form of exerting psychological forces which are more mental.

The difference between biological and psychological factors in human behavior is that biological factors view humans as pure and simple organisms, while psychological factors view humans as intelligent organisms, organisms that have intelligence. Because this is the case, humans in the process of physical (biological/body) and spiritual (psychological/soul) growth need guidance and direction through the educational process, so that their lives can be directed.

On the other hand, Arifin (1993) elaborates that guiding and directing physical growth and mental development in the sense of education, cannot be separated from psychological understanding. Through that paradigm, it causes humans to be called homo educandum (creatures that can be educated) and homo education (being educators). Therefore, human existence is as a pedagogic being, namely; a creature of the God that since his creation has brought the potential to be educated and able to educate.

Despite the fact that Islamic and Western education experts have explained a lot about human existence as a pedagogic creature, the writers view that the issue is still hot for critical and in-depth discussion.

The research aims to trace the origin of human creation, and the things behind it, so that humans are called pedagogic beings. Furthermore, the Islamic and Western conceptions of human existence as pedagogic beings will be presented. Thus, it is expected that this discussion will have scientific uses, namely as a reference material for understanding human existence as a pedagogic creature. 


\section{RESEARCH METHOD}

In this study, the type of research used was library research. The method of gathering data from library sources, reading and taking notes, and processing research materials are all part of library research, which is also known as literature study (Sugiyono, 2019). Moreover, Sari \& Asmendri (2018) defined that library research as a type of study that entails reading books, magazines, and other sources to gather information from a variety of sources, whether in libraries or elsewhere. It is clear from the foregoing description that library research entails more than just reading books and taking notes on the information gathered. But, more importantly, the researcher must be able to interpret and analyze the data gathered during the literature review process.

\section{RESULTS AND DISCUSSION}

\section{The Essence of Human Creation in Terms of Educational Aspects}

In terms of discussing educational problems, they are always associated with human problems. Therefore, educational problems that arise are never separated from human problems themselves. This is due to human involvement in the educational process is apart from being the subject as well as the object being the target in education. So that almost all problems that arise in the educational process involve humans. Thus, what must first be studied is the essence of human creation as an object and subject of education.

By referring to the Koran, it is found that the verses that explain the process of human creation always point to the term klahaqa (Al-Ashfahāni, 1992) dan ja'ala (AlAshfahāni, 1992) simultaneously. However, it seems that the earlier term khalaqa is mentioned, then the term ja'ala follows. For example, in the following verses as a sample (QS. al-Mu'minun [23]: 12-13) (QS. al-Sajadah [32]: 7-8) (QS. al-Insān [76]: 2):

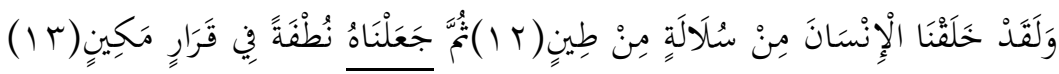

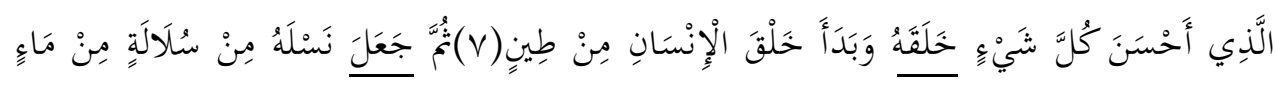

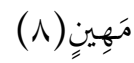

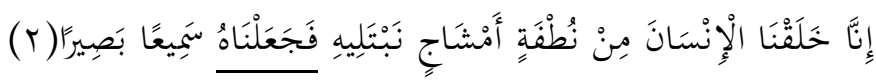

The writers do not intend to further analyze the terms khalaqah and ja'ala, but it is sufficient to refer to Nurbayan (2019) who stated that the word khalaqa (to create) contains the basic meaning of giving physical and psychological forms. While the word ja'ala (make) contains a double meaning, and one of its meanings is a legal connotation, which is to determine a position. With this kind of interpretation, it can be understood that in the process of human creation, there are at least two things that are related to the educational process, that are presented on the followings.

First, one of the methods used by the Koran to lead people to live the God's instructions is to introduce the human identity itself, how it happened, and where it came 
from. It needs to be reminded by humans through the educational process because the waves of life often cause people to forget themselves (Sanjaya, Kadir, \& Bahri, 2019). stated that because human position awareness is so important in the educational process, it is no surprise that early education activities always place a strong emphasis on human nature. This is understandable since education cannot function well without a solid foundation in human nature.

Second, the verses about the human event process that have been described implicitly also reveal His greatness and majesty in creating man, so that it has implications for increased insight. This means that education is included as a process of increasing knowledge and insight. Lyu (2019) stated that the development of humans' knowledge depends upon the internal and external senses. In this case, the external senses include the sight, smell, hearing, taste, and touch, all at once. While the internal senses do not have particular organs, they are intellectually connected to physical intermediaries.

By looking at the meaning of khalaqa and ja'ala, as well as their relation to the results of the above interpretation, it can be further formulated that humans consist of two substances, namely bodies or matter, and non-body or immaterial substances. The body is a substance whose basic material is matter originating from the universe, and in its growth and development, it is subject to the God's provisions. Whereas non-bodies are the blowing of His created spirit into humans, so that humans are organic objects that have a human nature (al-haqiqqah al-insāniah), and have natural potential that can be educated and can also educate. This means that the implication of human life is to be involved in educational endeavors.

In this connection, it is not a coincidence that the first verse revealed by Allah Almighty was a reading command "إقز (read it!). The question is, what to read? The answer is, of course, the verses of the Koran and natural phenomena. To get to that goal, one has to go through a process called education. Zambrano R. et al., (2019) stated that individuals will learn what they have never known by reading, and humans will be able to discriminate between good and bad by reading.

It is recognized that humans are born without the slightest knowledge, but in humans, there are basic potentials that allow them to develop. With these potentials, humans have to make the best use of them.

\section{Setting History of Humans as Pedagogic Beings}

After understanding the essence of human creation and the essence of humanity as described in the previous description, it will in turn lead to the formulation of man as a pedagogic being.

Daradjat in Nunzairina (2018) defines that a pedagogic being as:

"The God's creatures who are born to carry the potential to be educated and can educate. The creature is human. It is he who has the potential to be educated and educate so that he can become the caliph on earth, supporting and developing culture. $\mathrm{He}$ is equipped with the nature of Allah, in the form of skills and abilities that can be developed. Thoughts, feelings, and the abilities to act are components of that nature." 
If the above definition is related to the nature of human creation, then there is a reconciliation that the main cause of a man so that he can be educated and educated is because of the natural potential in the form of physical and psychological aspects that can grow and develop through pedagogical processes and interactions. In Hasan Langgulung's view, that a man, who consists of two substances, has been equipped with potential tools and basic potential called fitrah Hasan Langgulung in (Fadilah \& Tohopi, 2020). This fitrah (which is in the definition of Zakiah Daradjat above), must be actualized and developed in life through the educational process.

Understanding of human nature can be traced further in QS. al-Rum/30: 30.

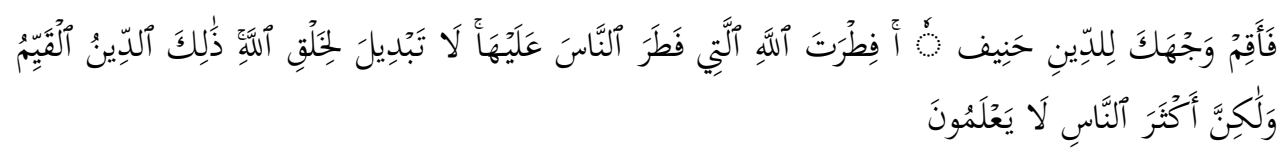

"So, turn your face straight to the religion (Allah); (stay on top) the nature of Allah who created man according to that nature. There is no change like Allah. (That is) the straight religion; but most humans do not know."

In al-Ashfahāni's view that the term fithratallahi in the above verse contains an interpretation of the existence/power to know or acknowledge Allah who resides in humans (Al-Ashfahāni, 1992). Thus, the implication of the meaning of fithrah is a power or ability that remains in humans from the beginning of their birth, for commitment to the values of faith in Him, tends to the truth and that potential is His creation.

This Fithrah must be developed in an integrated manner by humans and actualized in everyday life, both individual and social life. With this fithrah, it is also what distinguishes humans from other creatures of Allah, and because of that, humans become special and nobler, which at the same time means that humans are pedagogical creatures (Nunzairina, 2018). Allah has indeed created all of His creatures based on His fithrah, but Allah's fithrah for humans, which here is translated as the potential to be educated and educate, has the possibility of developing and increasing so that their abilities can far exceed their undeveloped physical abilities.

In Abdurrahman Saleh Abdullah's view, through the educational process, humans can freely grow this fithrah (Mappasiara, 2017). However, in the writers' point of view, its development cannot be separated from the existence of certain limits, namely the existence of definite and permanent laws that control nature (sunnatullah), or laws that control objects or humans themselves, which are not subject to and do not depend on human will. These laws are called taqdìr (Majdi, 2019).

Besides, the growth and development of human fithrah are influenced by the heredity of the natural and geographical environment, the socio-cultural environment, history, and temporal factors. In Education Science, five factors determine the success of the implementation of education, namely; objective factors, educators, students, educational tools, and the educational environment (Mappasiara, 2017). Therefore, the interests, talents, abilities, skills, and attitudes of humans are manifested in their endeavors and the results will vary. 
On the other hand, if human fithrah was not developed through a pedagogical process, then it would have little meaning in life. Or in other words, with education and teaching, that potential (fithrah) can be developed by humans, even though they are born like white paper, clean and do not contain anything, and even though they are born with a nature that can develop on their own, this development will not progress if they do not go through a certain process, namely the educational process.

According to Zakiah Daradjat, the obligation to develop this potential is a human burden and a responsibility to the God. The possibility of developing that potential means that humans may be educated, and at the same time, one day they may educate (Nunzairina, 2018).

If we re-refer to the essence of human creation and the essence of human life, then it is known that indeed, humans are potentially creatures that deserve to be burdened with obligations and responsibilities, accept and implement the God's teachings absolutely as their creators.

\section{Islamic and Western Views of Humans as Pedagogical Beings}

\section{Islamic View of Humans as Pedagogical Beings}

From previous descriptions, it appears that Islam views humans as pedagogical beings based on their physical and spiritual structures. From this human structure, Allah provides a set of basic abilities which tend to develop. This basic ability is called fithrah.

The term "Fitrah" can be interpreted in a variety of ways. As described in surah alRum verse 30, the first thing created by the God is the religion (Islam) as a direction or reference, and human beings are formed in the best condition based on this reference. Due to a multitude of bad elements that impact them, a person's position can be "moved" away from their Fitrah, necessitating the need for guidance, such as warnings and direction from Allah, provided through His Messenger (Saryono, 2017).

In the Islamic view, human existence as pedagogical beings allows the development of his fithrah following the path and/or educational environment he faces. The path of education referred to here is formal education in the school environment, non-formal education in the community, and informal education in the household environment (Irawati \& Susetyo, 2017). These three lines of education are called tripusat education (Sumiana, 2020).

When the fithrah is "polished", the first and foremost determining is the informal education path. It is said so because the household environment is the first place a person gets an education. In other words, from the first time a child is born in this world, it is the parents who have the earliest influence. This means that the growth and development of fithrah start from informal education, in which both parents act as educators in a bilingual way. This is based on the hadith narrated by Abu Huraerah, namely: 


$$
\text { عي ابي هريرة رض الله عنه قال : قال النبي صلى الله عليه وسلم : كل مولد يولد على الفطرة فابواه يهودانه او ينصرانه }
$$

"From Abi Hurairah ra, that the Holy Prophet said: every child who is born in a state of fitrah, then the parents make him a Jew, Christian or Magi" (Al-Naisaburi, 1797).

The context of the hadith is relevant to QS. al-Rum/30: 30 as quoted earlier, which both talk about the nature of faith as a guide for parents to be more existent in directing the religious attitude of each child wisely. Based on this, Islam views that the growth and development of human fithrah as pedagogical beings is greatly influenced by the family environment. Because it is in this environment that children receive several values and norms instilled in them from the start. In connection with that Mappanganro (1993) stated that at that time, the child's faith was not a belief as a result of objective thinking, but was more a part of the natural life of feelings which was closely related to their mental needs for love, security, and physical enjoyment. Child worship at this time is still an imitation and a habit that is not lived up to (Mappanganro, 1993). Juditha (2015) formulated that there are three categories of religious behavior of the Makassar people in the aspect of praying, namely: very diligent, diligent, and less diligent. Rama concluded that there are differences in these categories due to the growth and development of different fithrahs in society.

Based on the results of the above research, it indicates that the growth and/or development of human fithrah as pedagogical beings is still influenced by environmental factors. Furthermore, for this fithrah to grow and develop following the concept of Islamic teachings, Muslims are required to maintain their faith and then increase it through the process of Islamic education. Islamic education means the formation of a Muslim person. The content of a Muslim person is the full practice of the teachings of Allah and His Messenger. Fostering the Muslim person is obligatory, and because the Muslim person cannot possibly be realized except with education, that education is an obligatory in the view of Islam. In the rules of ushul fiqh it is said mālā yatimmu syaiun illā bihi fahuwa wäjibun "something imperfect is an obligatory action except with it, then something is obligatory".

\section{Western Views of Humans as Pedagogical Beings}

In several verses previously quoted (see part II sub-A), it is explained in detail and thoroughly that, in the view of religion (Islam), man is created from dust and soil (matter) and then the divine spirit is blown (immaterial), describing the essence of creation. humans and human life are very perfect with the combination of two elements, namely physical and spiritual.

However, from the Western perspective, there is no detail and accuracy found regarding the nature of human creation itself. Many of them still adhere to Darwin's theory, which assumes that humans were created through a long evolutionary process (from 
monkeys) (Anemone, 2021). This Darwin's theory places man on a par with animal and explained the occurrence of man or the nature of human creation from mechanical causes (Kauffman \& Gare, 2015).

Still related to the Western view of human nature, Prof. Dr. H. Azhar Arsyad, MA., stated that there are some experts (Western education experts) talking about humans who only describe one or two aspects of humans. For example, they describe that "humans are intelligent mammals". Furthermore, Azhar Arsyad argues that this example does not describe humans as a whole (Arsyad, 2002).

In the writers' view, it is true that, from a purely biological perspective, humans are a kind of animal, because they are also breastfeeding. Animals have ribs and humans do too. However, in the physiological aspect, it is not the same between humans and animals, because humans are intelligent creatures while animals are not.

The understanding of humans as biological creatures has led to a study called biopaedagogic or educational biology, carried out by pedagogic and psychological experts. Such is the magnitude of this biological understanding so that they argue that there is a crime and the problem of naughty children is due to heredity (biological descent) (Nikita, Karatzia-Stavlioti, \& Alahiotis, 2015). Likewise, a psychologist from the West named Lombrosso (Britannica Online Encyclopedia, 2021) determines the traits and characteristics of certain criminals.

One of the theories in educational psychology is about "physiognomy". The main character who adheres to the teachings of physiognomy is Lombrosso. By adhering to this theory of physiognomy, Lombrosso believed that the characteristics of people were given at birth and would not change again in their life. Likewise, criminals have acquired evil talents from birth and these talents are reflected on a person's face (Martinich, 2014).

Furthermore, Lombrosso argued that human nature from birth can also be called the delinquent nato theory, namely the potential or talent that affects the face and body parts of the person concerned (Sarwono, 2005). Because of that, Lombrosso with this theory, argued that to say that a person is a criminal or not a criminal can be seen from his face and the pieces of his body.

If Lombrosso's opinion is held, it is enough to study the shape of a person's face, or simply by paying attention to his posture, it can be guessed that the person is evil or not evil. In other words, based on certain facial expressions and physiological forms (body), Lombrosso classified humans into two types, namely the criminal type and the noncriminal type (Sarwono, 2005).

The formula used to determine a person's personality by paying attention to facial expressions is to measure the shape of the skull (cephalic index). In this case, the skull index is obtained by calculating the ratio (ratio) between the length and width of the skull, or by adding the distance between the roof of the skull and the base of the skull. In this way, three types of skulls are obtained, namely:

1. Long head

2. Roundhead

3. A head that is shaped between long and round (Sarwono, 2005). 
Each type of head or skull shape indicates the presence of certain characteristics or personality traits that are the bearer of the results and cannot be changed. This understanding is closely related to the notion of racialization, namely that each race already has its own characteristics and personality traits that do not change anymore.

In the writers' view, the differences in the types above, both in terms of a person's facial expression and body posture, are sometimes visible and sometimes they are not. In other words, human personality, character, and nature do not always have to be guided by the theory of physiognomy as adopted by Lombrosso.

For the writers, problems of personality, character, and human nature can also be influenced by the experiences and the influence of the environment. So, the environment in which that person lives is the most important factor that shapes that personality. The opinion of the writers refers to the Islamic view that upholds human fithrah, as in the QS. al-Rum/30: 30 and the hadith narrated by Abu Huraerah that was quoted earlier.

If we trace human existence again by looking at the hereditary factor (heredity) that comes from parents, Islam recognizes this, but it has implications for education, which connotes nativism, and its emphasis continues to make fithrah a basic potential for the "dinulqayyim" religion that cannot be changed. This means that once Islam is adhered to be based on heredity, then its religious function will not change. However, if fithrah in the sense of religious potential (implementing religious teachings) is used as a benchmark, then, in turn, the level of diversity continues to grow and develop when it is "polished" through the educational process.

This understanding of nativism also comes from the viewpoint of Lombrosso, and a Western scholar named Schopenhauer (Ahmadi, 2020). However, the views of Lombrosso and Schopenhauer regarding humans as pedagogical beings are not the same as those of Islam. The Western view, represented by Lombrosso and Schopenhauer, states that the educational process as an effort to influence the souls of students is powerless to change it. Whereas in the Islamic view, it is that the educational process can affect the soul of the child.

It needs to be emphasized here, that not all Western education experts agree with Lombrosso and Schopenhauer regarding the concept of man as a pedagogical being. John Locke (1632-1704), for example, explained the essence of man by emphasizing the discussion of reason as a storehouse and developer of knowledge. According to John Locke, a man will have the strength and materials to train these powers (Dalyono, 2015; Widiana, 2009). It seems that John Locke's view is neutral. It is said that because of John Locke's view, humans are not born to be good or bad, but they depend on the power of reason to receive influence from outside (the environment).

In educational psychology, John Locke's views are categorized as behaviorism, which originated from American psychology and education scholars. The same thing was also stated by Skinner, that the environment around us determines the development of a person's life, but he can also change the environment (Prambudi \& Hoiriyah, 2019).

Still related to the Western view of humans, Rousseau with his philosophy of naturalism, based education on the progressive principle, namely his view that human 
nature is natural. Humans, according to him, are born from natural wombs that have good qualities. Therefore, this Western figure emphasized that in education, children should be kept away from unfavorable environments. In education, there should be no definition of "power", orders that must be obeyed; give the child back to himself. Education prioritizes children's interests and needs. Therefore, the school program will be programmed/organized around and according to the interests and needs of the child (Syarifudin \& Kurniasih, 2020).

Based on Rousseau's view, it can be understood that in education there is an interaction between individuals and their environment through a process of transmission. So according to him, to educate children well, a good educational environment must also be well organized.

By listening to the views of John Locke, Skinner, and Rousseau again, it can be understood that the soul of the child from birth is in a good state, pure as a wax (tabularasa). which passively receives the influence of the external environment. So, it can be formulated that the Western view represented by John Locke, Skinner, and Rosseau is actually in line with the Islamic view that humans can essentially grow and develop their knowledge through the educational process.

Growth is a change in behavior that takes place continuously to achieve a further result. The potential capacity possessed by humans is a capacity that can grow into something different, because of the influence that comes from outside. Therefore, in addition to internal factors, humans will also be influenced by external factors in the form of the environment. Therefore, the environment is one of the determinant factors in the success of the educational process.

\section{CONCLUSION}

From the descriptions that have been described earlier, it can be concluded that the essence of human creation from the Islamic perspective by referring to the text of the Koran, always points to the terms klahaqa (to create) and/or ja'ala (to make). These two terms inform that humans are created by two elements, namely matter and immaterial. The two elements mentioned above can grow and develop through the educational process. Thus, humans can be called homo educandum (creatures that can be educated) and homo education (being educators). From this paradigm, it has caused human existence since birth, or in terms of physical human existence, it is called a pedagogical being, namely, a creature of the God that since his creation has brought the potential to be educated and able to educate.

Moreover, in the view of Islam, human fithrah is a religious potential that is carried from birth and this potential can grow and develop. The level of growth and development, along with the pedagogical process that initiates it, involves informal education, formal education, and non-formal education. Meanwhile, in the Western view, two categories are found. First, the view with nativism understanding that human fithrah cannot be changed through the educational process. Second, a view of behaviorism, which assumes that human fithrah is possible to change through the educational process. 
By comparing the Islamic and Western views on the position of humans as pedagogical beings, it leads to an implication that the Islamic view is more perfect. The reason is that human fithrahs according to Islam are dynamic, so that they are not only built into the behavioral paradigm but also into the empirical paradigm.

\section{REFERENCES}

Ahmadi, A. (2020). Ilmu Pendidikan Islam sebagai Perspektif Kehidupan. AL-FIKR: Jurnal Pendidikan Islam, 5(2). https://doi.org/10.32489/alfikr.v5i2.27.

Al-Ashfahāni, A.-R. (1992). Mu'jam al-Mufradāt Alfāzh al-Qur'ān. Bairut: Dār al-Fikr.

Al-Naisaburi, I. I. H. M. bin H. I. M. al-Q. (1797). al-Jami Shahih (Juz VIII). Beirut: Dar alMa'arif.

Anemone, R. L. (2021). Charles Darwin and Evolutionary Theory. In Race and Human Diversity. https://doi.org/10.4324/9781315662985-8.

Arifin. (1993). Ilmu Pendidikan Islam; Suatu Tinjauan Teoritis dan Praktis Berdasarkan Pendekatan Interdisipliner (Cet.II). Jakarta: Bumi Aksara.

Arsyad, A. (2002). Superioritas Konsep Pendidikan Islam. Seminar IAIN Alauddin. Makassar: IAIN Alauddin.

Britannica Online Encyclopedia. (2021). Education - Britannica Online Encyclopedia.

Dalyono, M. (2015). Psikologi Pendidikan Islam. In Cirebon (Vol. 4).

Fadilah, F., \& Tohopi, R. (2020). Fitrah dalam Pendidikan Islam Menurut Hasan Langgulung. Jurnal Ilmiah AL-Jauhari: Jurnal Studi Islam Dan Interdisipliner, 5(2). https://doi.org/10.30603/jiaj.v5i2.1814.

Irawati, E., \& Susetyo, W. (2017). Implementasi Undang-undang Nomor 20 Tahun 2003 tentang Sistem Pendidikan Nasional di Blitar. Jurnal Supremasi, 7(1). https://doi.org/10.35457/supremasi.v7i1.374.

Juditha, C. (2015). Stereotip dan Prasangka dalam Konflik Etnis Tionghoa dan Bugis Makassar. Jurnal Ilmu Komunikasi, 12(1). https://doi.org/10.24002/jik.v12i1.445.

Kauffman, S. A., \& Gare, A. (2015). Beyond Descartes and Newton: Recovering life and humanity. Progress in Biophysics and Molecular Biology, Vol. 119. https://doi.org/10.1016/j.pbiomolbio.2015.06.003.

Lyu, F. (2019). Architecture as spatial storytelling: Mediating human knowledge of the world, humans and architecture. Frontiers of Architectural Research, 8(3). https://doi.org/10.1016/j.foar.2019.05.002.

Majdi, A. L. (2019). Metodologi Pembaruan Neomodernisme dan Rekonstruksi Pemikiran Islam Fazlur Rahman. NALAR: Jurnal Peradaban dan Pemikiran Islam, 3(1). https://doi.org/10.23971/njppi.v3i1.1196.

Mappanganro. (1993). Masa Kanak-Kanak dan Perkembangan Rasa Keagamaan. Warta Alauddin" Tahun XII No. 66.

Mappasiara. (2017). Filsafat Pendidikan Islam. Inspiratif Pendidikan, 6(2). https://doi.org/10.24252/ip.v6i2.5231.

Martinich, a. P. (2014). Encyclopedia Britannica. 12-5-2014. 
Nikita, V., Karatzia-Stavlioti, E., \& Alahiotis, S. (2015). Evaluating the Pedagogical Effectiveness of the New Learning Theory of "Biopedagogism". International Journal of Assessment \& Evaluation, 22(4).

Nunzairina, N. (2018). Sejarah Pemikiran Psikologi Islam Zakiah Daradjat. JUSPI (Jurnal Sejarah Peradaban Islam), 2(1). https://doi.org/10.30829/j.v2i1.1793.

Nurbayan, Y. (2019). A Semantic Analysis of Words "Khalaqa, Ja'ala, Bada'a, Shana'a, Fathara" in Revealing the Concept of Human Creation. Arabiyat: Jurnal Pendidikan Bahasa Arab dan Kebahasaaraban, 6(2). https://doi.org/10.15408/a.v6i2.13106.

Prambudi, S., \& Hoiriyah, N. (2019). Penerapan Teori Operant Conditioning B.F. Skinner dalam Pembelajaran Pendidikan Agama Islam (PAI) di Sekolah. Studi Islam, 3(2252).

Sanjaya, B. D., Kadir, S., \& Bahri, F. (2019). Analisis Kemiskinan di Kota Pagar Alam. Jurnal Ekonomi Pembangunan, 16(2). https://doi.org/10.29259/jep.v16i2.8888.

Sari, M., \& Asmendri. (2018). Metode Penelitian Kepustakaan (Library Research). Penelitian Kepustakaan (Library Research) dalam Penelitian Pendidikan IPA, 2(1).

Sarwono, S. W. (2005). Pengantar Psikologi Umum. Yogyakarta: Rajawali Pers.

Saryono. (2017). Konsep Fitrah dalam Perspektif Islam. Medina-Te, 12(2).

Sugiyono. (2019). Metode Penelitian Pendidikan. Bandung: Alfabeta.

Sumiana. (2020). Zonasi dan Merdeka Belajar : Kajian Kritis dari Prospektif Kebijakkan. Buana Pendidikan: Jurnal Fakultas Keguruan dan Ilmu Pendidikan, 16(30). https://doi.org/10.36456/bp.vol16.no30.a2712.

Syarifudin, T., \& Kurniasih. (2020). Pedagogik Teoretis Sistematis. In Percikan Ilmu.

Widiana, S. H. (2009). Landasan Konseptual Teoritik Psikologik dari Berbagai Teori Inteligensi. Humanitas (Jurnal Psikologi Indonesia), 6(1).

Zambrano R., J., Kirschner, F., Sweller, J., \& Kirschner, P. A. (2019). Effects of prior knowledge on collaborative and individual learning. Learning and Instruction, 63. https://doi.org/10.1016/j.learninstruc.2019.05.011. 